\title{
AN INTEGRATED TREATMENT OF BASIL OIL (OCIMUM BASILICUM) AND ALUM WITH MODIFIED ATMOSPHERE TO CONTROL CROWN ROT DISEASE IN EMBUL BANANA
}

\author{
K Abeywickrama ${ }^{1 *}, \mathrm{C}$ Wijerathna ${ }^{1}$, H Herath $^{1}$ and KH Sarananada ${ }^{2}$ \\ ${ }^{1}$ Department of Botany, University of Kelaniya, Kelaniya, Sri Lanka \\ ${ }^{2}$ Food Research Unit, Gannoruwa, Peradeniya, Sri Lanka
}

Accepted: 01 ${ }^{\text {st }}$ June 2009

\begin{abstract}
A study was undertaken with the objective of developing environmental friendly integrated treatment strategies for controlling crown rot disease in Embul banana. The fungicidal potential of $1 \%$ alum (sodium aluminium sulphate) was observed in vitro. Findings indicate that alum+basil oil $(0.16 \%$ or $0.20 \% \mathrm{v} / \mathrm{v}$ ) treated 80, 85, 90 day mature Embul banana fruits were relatively free from crown rot disease after subjecting to modified atmosphere packaging (MAP) and storage at optimum temperature. Crown rot disease severity of 85-day mature and vacuum packed $1 \%$ alum $(w / v)$ washed banana was lower and comparable to carbendazim (bavistin) treatment. After ripening, there was no significant difference in physico-chemical properties (titratable acidity, total soluble solids, $\mathrm{pH}$, fruit firmness) of all treated fruits compared to the control. Sensory properties were slightly affected as compared to untreated fruits. MAP and vaccum packaging in combination with alum and/ or basil oil spray treatments at $12-14^{0} \mathrm{C}$ could extend the storage life of Embul banana upto 32 days which could be recommended for sea shipment.
\end{abstract}

Key words: Crown rot, Embul banana, Essential oils, Post harvest disease control

\section{INTRODUCTION}

Embul banana (Musa acuminata-AAB) is a popular dessert fruit in Sri Lanka. Due to its small size and characteristic flavor, it has a high export potential in the European market (Anthony et al. 2003). The short storage life and crown rot disease are the major problems associated with the export of this commodity over long distances. Discoloration of infected tissues and detachment of fruits from the crown during handling would shorten storage life, decrease consumer appeal and affect quantity and quality of banana for local consumption and export (Ranasinghe et al. 2003; Anthony et al. 2004).

Research conducted in Sri Lanka have shown that the storage life of 'Kolikuttu' banana when kept at modified atmosphere, in a package containing low oxygen and high carbon dioxide concentrations, could be extended up to 21 days. (Illeperuma et al. 2000; Ranasinghe et al. 2005). The low temperature $\left(11-14^{0} \mathrm{C}\right)$ slows down the growth of micro organisms mainly fungi on banana fruits (Wills et al. 1982). In commercial export oriented operations, dehanded banana hands are washed in $1 \%$ $(\mathrm{w} / \mathrm{v})$ alum solution in a float tank to avoid latex staining (Wijerathnam 1996).

The maturity at harvest has a major effect on the quality and the storage life of fruit. Further, relative humidity (RH) also has a great effect on quality and the storage life of fruit (Grierson et al. 1978). Banana requires higher humidity when fruits are green (Hardenberg et al. 1986). However, dormant pathogens may develop rapidly in the humid atmosphere. Therefore, adequate decay control of sealed fruit is important (Ben-Yehoshua 1985).

Previous research trials conducted at the Department of Botany, University of Kelaniya, Sri Lanka indicated that the essential oil of Ocimum basilicum oil (basil oil) was fungicidal against crown rot fungal pathogens of banana fruit - Colletotrichum. musae, Fusarium proliferatum, Lasiodiplodia theobromae at a low concentration $0.08 \%$ (v/v) in a liquid bioassay (Anthony et al. 2004).

An emulsion spray of Indian sweet basil (Ocimum basilicum) when used at $0.16 \%(\mathrm{v} / \mathrm{v})$ was effective in controlling crown rot of Embul banana without adversely affecting the organoleptic and physicochemical properties (Anthony et al. 2003). The storage life of banana treated this way was lengthened up to 21 days when treated with alum and subsequent basil oil spray treatment. During a subsequent research project at University of Kelaniya, Sri Lanka, eugenol was identified as the most effective antifungal component of basil oil in inhibiting conidial germination of Colletotrichum musae and Fusarium proliferatum, in vitro. Both Ocimum basilicum and eugenol inhibited appressoria formation by Colletotrichum musae and changed the selective permeability of conidial membranes (Herath and Abeywickrama 2008).

The objective of the present study was to determine the controlling efficacy of crown rot of ba- 
nana (Var. Embul) by integrated treatment of alum, basil oil and modified atmosphere packaging. Moreover, the storage life of banana (var. Embul) due to above integrated treatment will be quantified.

\section{METERIALS AND METHODS}

\section{Determination of the effect of $1 \%$ alum (w/v) on the growth of crown rot pathogens of banana in a liquid bioassay}

The fungicidal effect of alum (1\% w/v) was assessed against crown rot causative agents of Colletotrichum musae, Fusarium proliferatum and Lasiodiplodia theobromae using a liquid bioassay. Fifty ml of SMKY medium [20g Sucrose, $7 \mathrm{~g}$ Yeast extract, $3 \mathrm{~g} \mathrm{KNO}_{3}$ and $0.5 \mathrm{~g} \mathrm{MgSO}_{4}$ in $1000 \mathrm{ml}$ of distilled water] was dispensed into $100 \mathrm{ml}$ conical flasks and autoclaved for $30 \mathrm{~min}$ at $1.03 \mathrm{Kgcm}^{-2}$ at $121^{\circ} \mathrm{C}$. Sodium aluminium sulphate $(0.50 \mathrm{~g})$ was added to each set of 6 flasks containing the sterilized and cooled SMKY medium. Carbendazim (Bavistin) $(500 \mathrm{mg} / \mathrm{L})$ (BASF Finlay (Pvt) Ltd. Colombo 2) added to another set of 6 replicate flasks served as the positive control (Anthony et al. 2004).

Each treatment was inoculated with a $5 \mathrm{~mm}$ fungal disc, cut using a sterilized cork borer from the periphery of a 7 day-old pure culture of each fungal pathogen. Contents were mixed thoroughly at room temperature for few minutes. Three sets of 6 replicate flasks were arranged according to a completely randomized design (CRD) on a laboratory bench and incubated for 7 days at $28 \pm 2^{\circ} \mathrm{C}$. Subsequently, fungal discs showing no further growth were transferred to freshly prepared PDA plates and incubated for further 7 days. After the incubation period, whether there is any growth of fungal mycelia from discs was observed and the lethal effect of alum and carbendazim were determined (Anthony et al. 2004).

\section{In vivo Bioassays preparation of treatments and control}

Ocimum basilicum (basil oil) was purchased from Aromatica laboratotries (Pvt) Ltd. Colombo Sri Lanka. The oil concentrations for in vivo bioassays were selected based on Minimum Lethal Concentration (MLC) of the oil against banana fungal pathogens, which was identified previously by Anthony et al. (2004). Basil oil $(160 \mu 1$ or $200 \mu 1)$ was added respectively to $100 \mathrm{ml}$ of distilled water samples to prepare $0.16 \%(\mathrm{v} / \mathrm{v})$ and $0.20 \%(\mathrm{v} / \mathrm{v})$ concentrations with a drop of Turkey Red Oil (saponified caster oil, emulsifying agent of food grade, Loyal Trading Company, Chennai). The mixture was stirred using a magnetic stirrer for
10 min to obtain an emulsion and mixed well by shaking.

Carbendazim (Bavistin systemic fungicide; $500 \mathrm{mg} / \mathrm{L}$ ) was prepared by adding $100 \mu \mathrm{l}$ of bavistin (BASF Finlay (Pvt) Ltd., Colombo 2) to $100 \mathrm{ml}$ of distilled water and stirring for $10 \mathrm{~min}$ using a Magnetic Stirrer. Sodium aluminium sulphate (alum) $(1 \% \mathrm{w} / \mathrm{v})$ solution (Rathee Chemical Colombo 11) was prepared by dissolving $1 \mathrm{~g}$ of sodium aluminium sulphate in $100 \mathrm{ml}$ distilled water. The control [ $\mathrm{C} 1$ for experiment $1, \mathrm{C} 2$ for experiments 2$5]$ was prepared by adding one drop of Turkey Red Oil to $100 \mathrm{ml}$ of distilled water and stirring on a magnetic stirrer for $10 \mathrm{~min}$.

\section{Experiment 1}

Embul banana bunches approximately 72 daymature with no record of pre or post harvest fungicidal treatment were harvested from a banana plantation in Hambantota District and transported to the pack house facility at Yobheeda Associates, Industrial Park, Hambantota, Sri Lanka. Approximately $1 \mathrm{~kg}$ hands were randomly selected as experimental units. Weights of hands were recorded using a digital balance. Each hand was washed in water to remove dirt and then in sodium aluminium sulphate (alum) $(1 \% \mathrm{w} / \mathrm{v})$ solution to remove latex (Anthony et al. 2003). All hands were allowed to air dry for half an hour on a packhouse bench. Cut crown surfaces and fingers of three replicate banana hands were sprayed with $0.20 \%$ (v/v) Ocimum basilicum oil emulsion, Carbendazim or control (C1). Excess solutions were allowed to drain for $10 \mathrm{~min}$. Oil treated, control and carbendazim treated banana hands were placed in low density polyethylene (LDPE) bags (31.5 x $32 \mathrm{~cm}^{2}$ surface area) as individual hands. Mouths of bags were tied with rubber bands and three replicate bags of each treatment/ control were packed in ventilated telescopic type, 3 -ply cardboard cartons (15.5" x 13.5" x 7") lined with perforated manila paper. For each treatment/ C1 two replicate boxes were used. The experimental arrangement was a CRD. All treatments and C1 were stored at $13-14{ }^{\circ} \mathrm{C}$ in a Cold Room for 21 days at $94-95 \%$ relative humidity (Anthony et al. 2003; Hewage 1996). Observations were made once a week and the samples were removed from cold storage for ripening induction after 21days. The experiment was repeated once. The experimental arrangement was a CRD.

\section{Experiment 2}

As indicate in experiment 1, Embul banana bunches approximately 80 day mature with no records of pre harvest fungicidal treatment were harvested and purchased from a banana plantation in Wewalduwa, Sri Lanka and dehanded. Hands were transported to University of Kelaniya, Botany laboratory and 
hands were cleaned as in experiment 1 (Anthony et al. 2003; Hewage 1996). All hands were washed in alum solution except control hands. Nine hands were sprayed with a basil oil emulsion of $0.16 \%(\mathrm{v} /$ v). Similarly, another set was subjected to $0.20 \%$ (v/v) basil oil emulsion whereas, the third set of nine hands was sprayed with 500ppm carbendazim solution. Fourth set of hands were sprayed with control (C2 - water + TRO) (Anthony et al. 2003). Three hands from each treatment including $\mathrm{C} 2$ were placed in LDPE bags $(0.076 \mathrm{~mm}$ thickness / 150 gauge) of $40 \mathrm{~cm} \times 75 \mathrm{~cm}$ surface area. Each bag of 3 replicate hands were placed in a ventilated telescopic type, 3-ply cardboard carton (18" x 35" x 40 ") lined with perforated manila paper $(60 \mu)$. All treatments and $\mathrm{C} 2$ were stored as in experiment 1 for 32 days. The experiment was repeated once under identical conditions. The experimental arrangement was a CRD with three replicate boxes (per treatment/control).

\section{Experiments 3 and 4}

The same experimental procedure was followed for Embul banana bunches approximately 85 and 90 days mature as in experiment 2. This experiment was repeated once under identical conditions. The experimental arrangement was a CRD with three replicate boxes (per treatment/control).

\section{Experiment 5}

Embul banana of 85 day-mature were harvested from the banana plantation in Wewalduwa, Sri Lanka and transported to the Department of Botany laboratory. Hands were washed and treated with alum as in experiment 1. (Anthony et al. 2003, Hewage 1996). Nine hands each were treated with carbendazim systemic fungicide or control and three hands of banana from each treatment/control were placed in LDPE bags as in experiment 1.Air inside bags was sucked out using a vacuum cleaner before sealing the mouths of bags with rubber bands. The experimental arrangement was a CRD with three replicate boxes (per treatment/control). All treatments and control were stored as in experiment 2 for 32 days. This experiment was repeated once under identical conditions.

\section{Ripening of banana}

Banana fruits subjected to in vivo bioassays (experiments 1-5) were subjected to induced ripening by exposure to ethylene (ethral, 2-cloroethanephosphoric acid) (Harrisons Chemicals, Colombo, Sri Lanka) for $24-48 \mathrm{~h}$ at ambient temperature. When the fruits attained table ripe stage, i.e. $(\mathrm{CI}=$ 6), all fruits were assessed for pathological, physico -chemical and organoleptic properties as indicated below after each storage period (Hewage 1996).

\section{Pathological properties}

The area affected by crown rot on each hand was recorded using a standard index developed by Hewage (1996) as follows. [Crown rot (CRS) $\mathbf{0}=$ No rot, $\mathbf{1}=5 \%$ Crown rot, $2=50 \%$ Crown rot, $3=$ $75 \%$ Crown rot, $\mathbf{4}=100 \%$ rot, $\mathbf{5}=$ rot extending to the finger stalk]

\section{Physico-chemical analysis}

Eight randomly selected fingers from each treatment were analyzed for the following physicochemical properties.

Total Soluble Solids (TSS): A 10g sample of pulp from the middle of each finger was blended with $40 \mathrm{ml}$ of distilled water in a homogenizer for $2 \mathrm{~min}$. A few drops of the filtrate was used to measure total soluble solids) using a hand-held refractometer (Brix $0-32 \%)$. The actual TSS content $\left({ }^{0}\right.$ Brix) in the pulp was calculated by multiplying each reading by the dilution factor (Hewage 1996; Anthony et al. 2003).

Titratable Acidity (TA): Samples (10ml) of filtrates were diluted with $20 \mathrm{ml}$ of distilled water and titrated against $0.1 \mathrm{M}$ sodium hydroxide $(\mathrm{NaOH})$ with phenolphthalein as the $\mathrm{pH}$ indicator. The endpoint was taken as the sudden appearance of a slight pink colour. Titratable acidity (TA) (\% malic acid) was calculated by multiplying the $\mathrm{NaOH}$ volume required with the dilution factor and the malic acid factor (malic acid factor $=0.006706 \mathrm{~g}$ ). TA was expressed as \% malic acid (Anthony et al. 2003; Hewage 1996).

Fruit firmness: Fruit firmness $\left(\mathrm{kg} / \mathrm{cm}^{2}\right)$ of the pulp was measured using a fruit firmness tester. The probe was gently pressed against a cross cut section $(1 \mathrm{~cm}$ thickness) of a finger until it indicated a constant value (Hewage 1996).

Peel color: Peel color of banana fruits was visually determined using a Standard Color Index (SCI) developed at the Department of Botany, University of Kelaniya) [ $\mathbf{1}=$ Green, $\mathbf{2}=$ Colour break, $\mathbf{3}=$ More green than yellow, $\mathbf{4}=$ More yellow than green, $\mathbf{5}=$ Yellow with green tip, $\mathbf{6}=$ Full yellow , $7=$ Over ripe].

Weight loss: Banana hands were weighed before and after induced ripening using an electronic balance. The difference in the weight $(\mathrm{kg})$ was expressed as the percentage weight loss (Anthony et al. 2003; Hewage 1996).

pH: $\mathrm{pH}$ of the filtrate was measured using a digital $\mathrm{pH}$ meter (Hewage 1996). 


\section{Organoleptic properties}

Ten randomly selected fingers from each treatment/ control (selected from replicate boxes) were provided to a ten member taste panel with a questionnaire to evaluate the flavour, taste, odour and overall acceptability, using a numerical index of 0-100 (Herath 2005).

\section{Statistical analysis}

Data obtained for physico-chemical properties were subjected to one-way ANOVA and the mean separation was done using Tukey's Multiple Comparison test using Minitab version 14. Data obtained for pathological and organoleptic properties were subjected to Kruskal -Wallis non-parametric statistical test.

\section{RESULTS}

The Effect of $1 \%$ alum (w/v) on the Growth of crown rot pathogens of banana

Alum $(1 \% \mathrm{w} / \mathrm{v})$ was fungicidal against the three pathogens. No mycelial growth was observed in the liquid medium which was treated with $1 \%$ alum. When the fungal discs were transferred to freshly prepared PDA plates and incubated at room temperature $\left(28 \pm 2^{\circ} \mathrm{C}\right)$ for 7 days, mycelia did not revive. Pathogens grew profusely in the form of a mat on surface of the liquid medium in the control.

Assessment of Pathological, Organoleptic and Physico-chemical properties of 72 day mature Embul banana after storage in cold temperature in combination with MAP for 21 days and induced ripening (Experiment 1)

Pathological properties (crown rot disease severity): After induced ripening, control hands (which were initially washed in $1 \% \mathrm{w} / \mathrm{v}$ alum), demonstrated a relatively high crown rot severity of $50 \%$ $(\mathrm{CRS}=2)$. Crown rot disease was absent $(\mathrm{CRI}=0)$ in samples treated with $0.2 \%$ (v/v) O. basilicum oil emulsion combined with MAP and cold storage.

Table 1: Physico-Chemical Properties of Embul banana of 72 day maturity subjected to treatments, stored in MA and ripening induced

\begin{tabular}{lllll}
\hline Treatment & pH & $\begin{array}{l}\text { TA (\% Ma- } \\
\text { lic acid) }\end{array}$ & TSS $\left({ }^{\mathbf{0}} \mathbf{B r i x}\right)$ & $\begin{array}{l}\text { Fruit firm- } \\
\text { ness }(\mathbf{K g} / \\
\left.\mathbf{c m}^{2}\right)\end{array}$ \\
\hline Basil oil $(0.2 \%)$ & $4.08 \pm 0.02^{\mathrm{a}}$ & $0.67 \pm 0.03 \mathrm{a}$ & $20.42 \pm 0.42^{\mathrm{a}}$ & $0.48 \pm 0.01^{\mathrm{a}}$ \\
Control $(\mathrm{C} 1)$ & $4.08 \pm 0.02^{\mathrm{a}}$ & $0.63 \pm 0.02^{\mathrm{a}}$ & $20.00 \pm 0^{\mathrm{a}}$ & $0.48 \pm 0^{\mathrm{a}}$ \\
\hline
\end{tabular}

*Each data point represents the mean of 6 replicates \pm standard error.

** Means having a common letter(s) in the same column are not significantly different $(\mathrm{P} \leq 0.05)$ by Tukey's multiple comparison test
Organoleptic properties: Taste, flavour and odour of untreated 72-day mature embul banana of carbendazim treatment $(60-68 \%)$ was preferred by the taste panelists over banana treated with basil oil (44 $-61 \%)$ and the differences were statistically significant. Untreated banana that was in MAP were also less preferred (47-58\%) by the taste panelists and statistically similar to oil treatment.

Physicochemical properties: There was no significant difference in \% weight loss of banana treated with $0.2 \%$ (v/v) $O$. basilicum oil and banana without oil spray, stored in MA. pH, TA, TSS and fruit firmness of Embul banana stored in MAP, with and without oil spray, did not show a significant difference after storage at $13.5 \pm 2^{0} \mathrm{C}$ for 21 days and induced ripening (Table 1). After induced ripening, peels showed the highest and the preferable peel colour or table ripe stage ( $\mathrm{CI}=6$ or full yellow). When analyzed statistically, peel colour of banana treated with $O$. basilicum oil and controls were not significantly different.

Assessment of Pathological, Organoleptic and Physico-chemical properties of 80,85 and 90 day mature Embul banana after storage in cold temperature in combination with MAP for 32 days and induced ripening (Experiment 2-4)

Pathological properties: Crown rot disease severities of 3 maturity levels of banana treated with $1 \%$ alum wash were lower than that of the control. Statistically data were similar to the carbendazim treatment. $1 \%$ alum wash $+0.16 \%$ basil oil treatments of 85 and 90 day mature banana effectively controlled crown rot disease $(\mathrm{CRI}=<1)$. At 85 day maturity level, $1 \%$ alum wash $+0.20 \%$ basil oil treated banana controlled crown rot disease to a similar level as above and data were statistically similar to the carbendazim treatment (Table 2).

Table 2: Physico-Chemical Properties of Embul banana of 3 maturity stages subjected to treatments, stored in MA and ripening induced

\begin{tabular}{llll}
\hline \multirow{2}{*}{ Treatment } & \multicolumn{3}{l}{ Crown rot disease severity } \\
& \multicolumn{2}{l}{ Maturity stage / days } \\
& $\mathbf{8 0}$ & $\mathbf{8 5}$ & $\mathbf{9 0}$ \\
\hline Alum & $1^{\mathrm{b}}$ & $1^{\mathrm{b}}$ & $1^{\mathrm{b}}$ \\
Alum $+0.16 \%$ basil oil & $2^{\mathrm{a}}$ & $1^{\mathrm{b}}$ & $1^{\mathrm{b}}$ \\
Alum $+0.20 \%$ basil oil & $2^{\mathrm{a}}$ & $1^{\mathrm{b}}$ & $2^{\mathrm{a}}$ \\
Carbendazim & $1^{\mathrm{b}}$ & $0^{\mathrm{b}}$ & $0^{\mathrm{b}}$ \\
Control & $3^{\mathrm{a}}$ & $2^{\mathrm{a}}$ & $3^{\mathrm{a}}$ \\
\hline
\end{tabular}

* Each data point represents the mean of 18 replicates. ** Means having a common letter(s) in each column are not significantly different by Kruskal Wallis nonparametric statistical test $(\mathrm{P}=0.42)$. 
Organoleptic properties: The organoleptic properties (odour, taste, flavour and overall acceptability) of 80-day mature banana treated with $1 \%$ alum + basil oil $(0.16 \%$ or $0.20 \%)$ were less preferred (30$60 \%$ ) by the taste panelists than the control (50$70 \%$ ). However, odour, taste, flavour and overall acceptability of banana treated with $1 \%$ alum alone was preferred (50-70\%) by the taste panelists.

The taste panelists preferred the flavour, and overall acceptability of the essential oil treated 85 day mature banana in combination with alum where the scores were similar to the control $(50-70 \%)$ (Table 3).

The organoleptic properties of 90-day mature banana treated with $1 \%$ alum wash $+0.16 \%$ basil oil was not statistically different from the control, however the odour was least preferred (40\%). According to the results, $1 \%$ alum $+0.20 \%$ basil oil was preferred by the panelists $(57-70 \%)$ than $1 \%$ alum wash $+0.16 \%$ basil oil treatments $(40-60 \%)$ (Table 3).

Physico-Chemical Properties: At the end of the storage period, the peel colour of banana of all treatments belongings to the 3 maturity levels remained green and firm (Colour Index $(\mathrm{CI})=1$ ). After induced ripening, peel attained the highest and the preferable peel colour (table ripe stage or $\mathrm{CI}=6$ ) within 2-3 days. There was no significant difference in percentage weight loss of banana of all treatments regardless of harvesting maturity.

The fruit firmness of the pulp of the all treatments was not significantly different $(0.5-0.7 \mathrm{~kg} /$ $\mathrm{cm}^{2}$ ) at different maturity stages (Table 4). This was true for the banana of all 3 maturity levels. The Titratable Acidity (TA) values did not show a significant difference among treatments of 80-day and 90-day mature banana $(3.3-4.7 \%$ malic acid). A slightly lower value $(2.6 \%)$ was shown in $1 \%$ alum treatment of 85-day mature banana when compared to other treatments. All other treatments indicated

Table 3. Organoleptic properties (as a percentage) of Embul banana of 3 maturity levels subjected to treatments, stored in MA and ripening induced.

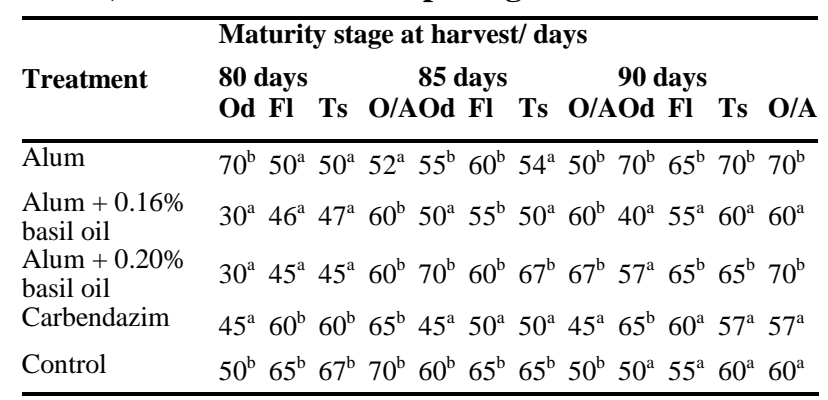

* Each data point represents the mean of 20 replicates.

** Means having a common letter(s) in the same column are not significantly different by Kruskal Wallis nonparametric statistical test $(\mathrm{P} \leq 0.05)$. Od - Odour; $\mathrm{Fl}$ Flavour; Ts - Taste, O/A - Overall Acceptability
Table 4: Physico-Chemical Properties of Embul banana of 72 day maturity subjected to treatments, stored in MA and ripening induced

\begin{tabular}{|c|c|c|c|c|c|c|}
\hline \multirow{3}{*}{ Treatment } & \multicolumn{6}{|c|}{$\begin{array}{c}\text { Fruit Firmness }\left(\mathrm{kg} / \mathrm{cm}^{2}\right) \text { Titratable Acidity (\% } \\
\text { Malic acid) }\end{array}$} \\
\hline & \multicolumn{3}{|c|}{$\begin{array}{l}\text { Maturity stage at har- } \\
\text { vest/ days }\end{array}$} & \multicolumn{3}{|c|}{$\begin{array}{l}\text { Maturity stage at har- } \\
\text { vest/ days }\end{array}$} \\
\hline & 80 & 85 & 90 & 80 & 85 & 90 \\
\hline Alum & $\begin{array}{l}0.60 \pm \\
0.03^{a}\end{array}$ & $\begin{array}{l}0.57 \pm \\
0.02^{\mathrm{a}}\end{array}$ & $\begin{array}{l}0.61 \pm \\
0.03^{\mathrm{a}}\end{array}$ & $\begin{array}{l}4.0 \pm \\
5.60^{\mathrm{a}}\end{array}$ & $\begin{array}{l}2.6 \pm \\
0.36^{b}\end{array}$ & $\begin{array}{l}4.2 \pm \\
0.12^{\mathrm{a}}\end{array}$ \\
\hline $\begin{array}{l}\text { Alum }+0.16 \% \\
\text { basil oil }\end{array}$ & $\begin{array}{l}0.60 \pm \\
0.04^{\mathrm{a}}\end{array}$ & $\begin{array}{l}0.53 \pm \\
0.02^{\mathrm{a}}\end{array}$ & $\begin{array}{l}0.70 \pm \\
0.02^{\mathrm{a}}\end{array}$ & $\begin{array}{l}3.7 \pm \\
0.10^{\mathrm{a}}\end{array}$ & $\begin{array}{l}3.6 \pm \\
0.21^{\mathrm{a}}\end{array}$ & $\begin{array}{l}3.3 \pm \\
0.12^{\mathrm{a}}\end{array}$ \\
\hline $\begin{array}{l}\text { Alum }+0.20 \% \\
\text { basil oil }\end{array}$ & $\begin{array}{l}0.58 \pm \\
0.02^{\mathrm{a}}\end{array}$ & $\begin{array}{l}0.60 \pm \\
0.01^{\mathrm{a}}\end{array}$ & $\begin{array}{l}0.60 \pm \\
0.03^{\mathrm{a}}\end{array}$ & $\begin{array}{l}3.6 \pm \\
0.18^{a}\end{array}$ & $\begin{array}{l}3.8 \pm \\
0.65^{\mathrm{a}}\end{array}$ & $\begin{array}{l}4.7 \pm \\
0.11^{\mathrm{a}}\end{array}$ \\
\hline Carbendazim & $\begin{array}{l}0.52 \pm \\
0.02^{\mathrm{a}}\end{array}$ & $\begin{array}{l}0.53 \pm \\
0.04^{\mathrm{a}}\end{array}$ & $\begin{array}{l}0.64 \pm \\
0.03^{\mathrm{a}}\end{array}$ & $\begin{array}{l}4.0 \pm \\
0.16^{\mathrm{a}}\end{array}$ & $\begin{array}{l}4.0 \pm \\
0.14^{\mathrm{a}}\end{array}$ & $\begin{array}{l}3.8 \pm \\
0.08^{a}\end{array}$ \\
\hline Control & $\begin{array}{l}0.52 \pm \\
0.03^{\mathrm{a}}\end{array}$ & $\begin{array}{l}0.60 \pm \\
0.03^{\mathrm{a}}\end{array}$ & $\begin{array}{l}0.64 \pm \\
0.03^{\mathrm{a}}\end{array}$ & $\begin{array}{l}3.6 \pm \\
0.15^{\mathrm{a}}\end{array}$ & $\begin{array}{l}3.8 \pm \\
0.22^{\mathrm{a}}\end{array}$ & $\begin{array}{l}4.3 \pm \\
0.08^{\mathrm{a}}\end{array}$ \\
\hline
\end{tabular}

* Each data point represents the mean of 6 replicates \pm Standard error

** Means having a common letter(s) in the same column are not significantly different $(\mathrm{P} \leq 0.05)$ by Tukey's multiple comparison test.

similar results. Titratable acidity values however, were similar in banana of different maturity stages except the maturity stage at 85 days after treating with alum (Table 4). The $\mathrm{pH}$ of the 80-day mature, treated banana showed a significant difference compared to the control (Table 4). The $\mathrm{pH}$ values of 85-day mature banana treatments were not significantly different except in $1 \%$ alum wash treat-

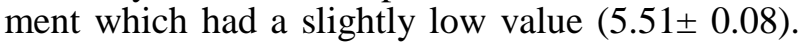
$\mathrm{pH}$ values of all analyzed samples of 90-day mature banana were similar.

There was no significant difference among total soluble solids contents of control and treatments except $1 \%$ alum wash $+0.16 \%$ basil oil treated 80 day mature banana, which showed a relatively lower value $(19.91 \pm 0.15)$. A significant reduction of TSS (20-24 ${ }^{0}$ Brix) of 85 -day mature banana was seen in $1 \%$ alum washed banana, while others were statistically not significantly different. Generally 90 -day or fully mature Embul banana treatment showed a higher TSS value (Table 5).

Assessment of Pathological, Organoleptic and Physico-chemical properties of 80,85 and 90 day mature Embul banana after vacuum storage in cold temperature for 32 days and induced ripening (Experiment 5)

Pathological properties: 85 day-mature, $1 \%$ alum washed and vacuum packed banana controlled the crown rot disease effectively where less than 5\% disease severity was observed. Results obtained were comparable to carbendazim treatment and control.

Organoleptic properties: Statistically, there was no significant difference in organoleptic properties of $1 \%$ alum sample compared to the control, except for the flavour which had a slightly lower score 
Table 5. Physico-Chemical Properties (pH and Total Soluble Solids) of Embul banana of 3 maturity levels subjected to treatments, stored in MA and ripening induced.

\begin{tabular}{|c|c|c|c|c|c|c|}
\hline \multirow{3}{*}{ Treatment } & \multicolumn{3}{|c|}{ pH value } & \multicolumn{3}{|c|}{$\begin{array}{l}\text { Total Soluble Solid con- } \\
\text { tent }\left({ }^{0} \text { Brix }\right)\end{array}$} \\
\hline & \multicolumn{3}{|c|}{$\begin{array}{l}\text { Maturity stage at har- } \\
\text { vest/ days }\end{array}$} & \multicolumn{3}{|c|}{$\begin{array}{l}\text { Maturity stage at harvest/ } \\
\text { days }\end{array}$} \\
\hline & 80 & 85 & 90 & 80 & 85 & 90 \\
\hline Alum & $\begin{array}{l}4.88 \pm \\
0.01^{\mathrm{a}}\end{array}$ & $\begin{array}{l}5.51 \pm \\
0.08^{\mathrm{b}}\end{array}$ & $\begin{array}{l}4.83 \pm \\
0.09^{\mathrm{a}}\end{array}$ & $\begin{array}{l}23.35 \pm \\
0.33^{\mathrm{a}}\end{array}$ & $\begin{array}{l}17.50 \pm \\
1.75^{b}\end{array}$ & $\begin{array}{l}25.08 \pm \\
0.32^{\mathrm{a}}\end{array}$ \\
\hline $\begin{array}{l}\text { Alum }+0.16 \% \\
\text { basil oil }\end{array}$ & $\begin{array}{l}4.70 \pm \\
0.04^{\mathrm{a}}\end{array}$ & $\begin{array}{l}5.68 \pm \\
0.01^{\mathrm{a}}\end{array}$ & $\begin{array}{l}4.75 \pm \\
0.07^{\mathrm{a}}\end{array}$ & $\begin{array}{l}19.91 \pm \\
0.15^{\mathrm{b}}\end{array}$ & $\begin{array}{l}20.67 \pm \\
1.08^{\mathrm{a}}\end{array}$ & $\begin{array}{l}23.33 \pm \\
0.90^{\mathrm{a}}\end{array}$ \\
\hline $\begin{array}{l}\text { Alum }+0.20 \% \\
\text { basil oil }\end{array}$ & $\begin{array}{l}4.76 \pm \\
0.15^{\mathrm{a}}\end{array}$ & $\begin{array}{l}5.56 \pm \\
0.10^{\mathrm{a}}\end{array}$ & $\begin{array}{l}4.83 \pm \\
0.09^{\mathrm{a}}\end{array}$ & $\begin{array}{l}24.41 \pm \\
0.30^{\mathrm{a}}\end{array}$ & $\begin{array}{l}24.50 \pm \\
0.71^{\mathrm{a}}\end{array}$ & $\begin{array}{l}25.25 \pm \\
0.21^{\mathrm{a}}\end{array}$ \\
\hline Carbendazim & $\begin{array}{l}5.01 \pm \\
0.03^{\mathrm{a}}\end{array}$ & $\begin{array}{l}5.66 \pm \\
0.04^{\mathrm{a}}\end{array}$ & $\begin{array}{l}4.58 \pm \\
0.13^{\mathrm{a}}\end{array}$ & $\begin{array}{l}24.50 \pm \\
0.16^{\mathrm{a}}\end{array}$ & $\begin{array}{l}23.83 \pm \\
0.47^{\mathrm{a}}\end{array}$ & $\begin{array}{l}25.00 \pm \\
0.13^{\mathrm{a}}\end{array}$ \\
\hline Control & $\begin{array}{l}5.20 \pm \\
0.03^{\mathrm{b}}\end{array}$ & $\begin{array}{l}5.73 \pm \\
0.03\end{array}$ & $\begin{array}{l}4.60 \pm \\
0.11^{\mathrm{a}}\end{array}$ & $\begin{array}{l}24.67 \pm \\
0.25^{\mathrm{a}}\end{array}$ & $\begin{array}{l}23.83 \pm \\
0.87^{\mathrm{a}}\end{array}$ & $\begin{array}{l}24.58 \pm \\
0.49^{\mathrm{a}}\end{array}$ \\
\hline
\end{tabular}

* Each data point represents the mean of 6 replicates \pm Standard error

** Means having a common letter(s) in the same column are not significantly different $(\mathrm{P} \leq 0.05)$ by Tukey's multiple comparison test.

than the control. The most preferred was the control which was given a higher $(80 \%)$ score for the odour by the taste panelists (Table 6).

Physico-chemical properties: There was no a significant difference in percentage weight loss, $\mathrm{pH}$, TSS, titratable acidity and fruit firmness of banana of all treatments regardless of maturity.

\section{DISCUSSION}

Alum, in vitro indicated fungicidal properties against banana fruit pathogens and in vivo controlled crown rot disease severity successfully irrespective of stage of maturity of Embul banana. Further, the integrated treatment of alum and basil oil (at $0.16 \%$ or $0.2 \%$ ) controlled the crown rot disease to a great extent specially when harvested at 85 day maturity and extended storage life up to 32 days in MAP and optimum temperature of $12-14^{0} \mathrm{C}$. The development of Alternaria alternata, the causative agent of the black spot disease of persimmon fruits (Diospyros kaki L.) was suppressed in cold storage for extended periods by $10-15 \% \mathrm{CO}_{2}$ developed inside the LDPE package in MAP (Prusky et al. 1997). The samples packed in LDPE did not ripen during the storage period due to MA created inside the packages. It has been reported that low oxygen and high carbon dioxide concentrations developing inside the package could decrease the rate of respiration, thereby delaying ripening (McGlasson \& Wills 1972). The optimum storage temperature for maximum green life is $13-14^{\circ} \mathrm{C}$; below this, chilling damage can occur (Hewage, 1996). Therefore, this treatment technology could be utilized to export Embul banana in commercial scale over long dis-
Table 6. Organoleptic properties of 85-day mature Embul banana treated with $1 \%$ alum wash or bavistin, subjected to vacuum, storage and ripening induced

\begin{tabular}{lllll}
\hline \multirow{2}{*}{ Treatment } & \multicolumn{3}{l}{ Organoleptic properties of banana } & \% Overall \\
& $\%$ Odour & $\begin{array}{l}\text { \% Fla- } \\
\text { vour }\end{array}$ & $\%$ Taste & $\begin{array}{l}\text { \%cceptabil- } \\
\text { ity }\end{array}$ \\
\hline Alum & $65^{\mathrm{b}}$ & $60^{\mathrm{a}}$ & $60^{\mathrm{b}}$ & $70^{\mathrm{b}}$ \\
Control & $80^{\mathrm{b}}$ & $70^{\mathrm{b}}$ & $70^{\mathrm{b}}$ & $70^{\mathrm{b}}$ \\
$\begin{array}{l}\text { Carben- } \\
\text { dazim }\end{array}$ & $50^{\mathrm{a}}$ & $60^{\mathrm{a}}$ & $47^{\mathrm{a}}$ & $60^{\mathrm{a}}$ \\
\hline
\end{tabular}

* Each data point represents the mean of 20 replicates. ** Means having common letter(s) in each column are not significantly different by Kruskal Wallis nonparametric statistical test.

tances where more than 30 days are required to reach the final destination.

Banana samples of 85 or 90 day mature treated with alum alone or alum+basil oil resulted in low disease severity $(\mathrm{CRI}=<1)$ on a $0-7$ hedonic scale and was similar to the observation seen when treated with carbendazim. Therefore, alum alone or oil+alum could potentially be used as an alternative to synthetic fungicides in the horticultural industry. According to our calculations the total cost of this type of treatment per $3 \mathrm{Kg}$ of banana inclusive of the cost of packaging and treatment would be approximately Rs 230 (US\$2). In addition, basil oil is readily available in India, Sri Lanka and other parts of the Asia indicating the easiness of adopting this treatment strategy. Essential oils of cinnamon bark and leaf oils have previously been tried out in Sri Lanka against postharvest decay due to anthracnose and crown rot (Ranasinghe et al. 2005).

In MAP stored 72-day mature Embul banana, (both treated and untreated with oil spray), there was no significant difference in physico-chemical properties (except \% weight loss). A research survey carried out by Illeperuma et al., (2000), indicated that \% weight loss of MAP stored 'Kolikuttu' banana was below $3 \%$ even at 30 days of storage. They have suggested that this may be due to the development of a saturated atmosphere in LDPE bags, which prevents moisture loss from the fruit (Illeperuma et al. 2000). Seventy days mature Embul banana samples treated with basil oil and subjected to MAP at cold storage, even though controlled crown rot disease, cannot be recommended for long storage as the samples were less preferred by the taste panelists when subjected to sensory evaluation. This could probably be due to the low maturity of fruits.

As the overall acceptability of alum treatment, carbendazim and control were almost similar after subjecting 85 day mature banana samples to vaccum packaging and cold storage, this treatment could also be recommended for super market storage and sea shipment. 
Basil oil treatments did not adversely affect the physico-chemical properties of banana of different maturity levels that were evaluated after induced ripening. At certain instances, organoleptic properties were slightly affected by alum or integrated treatment compared to the control. This indicates that the basil oil or alum treatment may have an effect on the complex biochemical changes associated with ripening however, the mechanism of the effect on these changes has not been determined. Previous research conducted in our laboratory indicated that when Embul banana were treated with $0.16 \%$ O basilicum and stored in corrugated boxes at $12-14^{\circ} \mathrm{C}$ (without MAP), O. basilicum at $0.16 \%$ did not affect the taste and flavour of banana and there was no significant difference between treated and the control when analyzed statistically (Anthony et al. 2003). Therefore, it could be stated that the effect of essential oils on organoleptic properties of banana may depend on the concentration of the essential oil and MAP.

Basil oil is considered as a 'generally regarded as safe' compound (Goubran \& Holmes 1993). In addition, volatile compounds from plants can inhibit the growth of fungal pathogens before evaporating without leaving any residue. Some of them are normal constituents of the human diet and are unlikely to be of any health risk (Hamilton- Kemp et al. 2000). Alum is currently being used in fruit industry to prevent latex dripping (Wilson Wijeratnam et al. 1996), and during the current study, the fungicidal potential of $1 \% \mathrm{w} / \mathrm{v}$ alum was demonstrated. Hence, we are confident that the novel treatment strategy of basil oil + alum +MAP or alum + vaccum packaging developed at the University of Kelaniya, Sri Lanka could be adopted as safe and environmentally friendly methods of treating Embul banana to control crown rot disease and extend storage life of banana.

\section{CONCLUSIONS}

Application of $1 \%$ alum and subsequent basil oil spray treatment $(0.16 \%$ or $0.20 \% \mathrm{v} / \mathrm{v})$ in combination with modified atmosphere packaging and cold storage could be recommended to control crown rot disease on three maturity levels $(80,85$ and 90 day mature) of Embul banana to lengthen their storage life up to 32 days. Eighty five day mature Embul banana treated with $1 \%$ alum and subjected to vacuum packaging could also be utilized to similarly extend the storage life of banana. It could be emphasized that this type of novel, eco-friendly treatments could be exploited and utilized in commercial scale sea shipment of banana to various destinations requiring greater than 30 days of voyage.

\section{ACKNOWLEDGEMENTS}

We wish to acknowledge the financial assistance provided by the International Foundation for Science (IFS), Sweden, Organization for the Prohibition of Chemical Weapons (OPCW), The Netherlands, and National Science Foundation (NSF), Sri Lanka. Authors thank the technical staff of the Department of Botany, University of Kelaniya, and Food Research Unit, Department of Agriculture, Gannoruwa, Sri Lanka for their assistance.

\section{REFERENCES}

Anthony S, Abeywickrama K and Wilson Wijeratnam S 2003. The effect of spraying essential oils of Cymbopogon nardus, Cymbopogon flexuosus and Ocimum basilicum on post harvest diseases and storage life of Embul banana. Journal of Horticultural Science and Biotechnology, 78 (6):780-5.

Anthony S, Abeywickrama K, Dayananda R, Wilson Wijeratnam S and Arambewela L 2004 Fungal pathogens associated with banana fruit in Sri Lanka, and their treatment with essential oils. Mycopathologia, 157 (1):91-7.

Ben-Yehoshua S 1985 Individual seal-packaging of fruit and vegetables in plastic film - A new post harvest technique. Hortscience, 20 (1):327.

Goubran FH and Holmes RJ 1993 The development of alternative fungicides from essential oils. Rural Industries Research and Development Report-DAV 54A, Institute for Horticultural Development, Victoria, Australia.

Grierson W and Warowski WF 1978 Relative humidity effects on the postharvest life of fruits and vegetables. HortScience, 13: 570-574.

Hamilton-Kemp TR. Archbold DD Loughrin JH Anderson RA McCracken CT Collins RW and Fallik E 2000 Stimulation and inhibition of fungal pathogens of plants by natural volatile phytochemicals and their analogs. Current Topics in Phytochemistry, 4:95-104.

Hardenburg RE, AE Watada and Wang CY 1986 The Commercial Storage of Fruits, Vegetables, and Florist and Nursery Stocks. U.S. Department of Agriculture Hand book 66.130.

Hewage KS 1996 Factors influencing postharvest longevity of Embul bananas. Ph.D. Thesis, Wye College University of London, UK.

Herath HM 2005 Effect of selected essential oil emulsion sprays in controlling crown rot pathogens of banana (Musa acuminata - Cultivar Embul). B.Sc. Dissertation, University of Kelaniya, Kelaniya. 
Herath $\mathrm{H}$ and Abeywickrama K 2008 In vitro application of selected essential oils and their major components in controlling fungal pathogens of crown rot in Embul banana. International Journal of Food Science and Technology, 43: 440447.

Illeperuma DCK, Theja Galappatty $\mathrm{P}$ and Sarananda KH 2000 Modified atmosphere packaging of 'Kolikuttu' bananas at low temperature. Journal of Horticultural Science \& Biotechnology, 75 (1): 92-6.

Mcglasson WB and Wills RBH 1972 Effect of oxygen and carbon dioxide on respiration, storage life and organic acids of green banana. Australian Journal of Biological Science, 25:35-42.

Prusky D, Perez A, Zutkhi Y and Ben-Arie R 1997 Effect of modified, atmosphere for control of black spot, caused by Alternaria alternata, on stored persimmon fruits. Phytopatholgy, 87:203 -8 .

Ranasinghe LS, Jayawardana B and Abeywickrama K 2003 Use of waste generated from cinnamon bark oil (Cinnamomum zeylanicum Blume) extraction as a post harvest treatment of Embul banana. Food, Agriculture and Environment, 1 (2): 340-44.

Ranasinghe LS, Jayawardena B and Abeywickrama K 2005 An integrated strategy to control postharvest decay of Embul banana by combining essential oils with modified atmosphere packaging. International Journal of Food Science and Technology, 40:97-103.

Wills RBH, Pitakserikul S and Scott KJ 1982 Effects of pre-storage in low oxygen or high carbon dioxide concentrations on delaying the ripening of bananas. Australian Journal of Agriculture Research, 33: 1029-36.

Wilson Wijeratnam RS, Sarananda KH and Abeyratne M 1996 Post harvest procedure for export of banana. CISIR postharvest series booklet \# 3, Agro and Food Technology Division, CISIR, Colombo, Sri Lanka. 